Zeszyty Naukowe Szkoły Głównej Gospodarstwa Wiejskiego w Warszawie

Problemy Rolnictwa Światowego tom 18 (XXXIII), zeszyt 4, 2018: 23-37

DOI: 10.22630/PRS.2018.18.4.94

Robert Mroczek $^{1}$

Instytut Ekonomiki Rolnictwa i Gospodarki Żywnościowej - Państwowy Instytut

Badawczy w Warszawie

\title{
Pozycja przemysłu spożywczego w łańcuchu żywnościowym w Polsce na przełomie XX/XXI wieku
}

\section{The Position of the Food Industry in Poland's Food Chain at the Turn of the $20^{\text {th }}$ to the $21^{\text {st }}$ Century}

\begin{abstract}
Synopsis. Przemysł spożywczy jest jednym z głównych ogniw (członów) gospodarki żywnościowej. Jest on największym odbiorcą nieprzetworzonych surowców rolnych, a zarazem głównym dostawcą żywności do sfery handlu (hurtowego i detalicznego). Znaczenie przemysłu spożywczego wzrasta też $\mathrm{z}$ tego powodu, że firmy przetwórcze często integrują podmioty biorące udział w procesie produkcji żywności od przysłowiowego pola do stołu. Sprzyja temu wzrost towarowości polskiego rolnictwa oraz rosnący popyt na żywność wysoko przetworzoną. W ostatnich latach przewagę w relacjach handlowych zyskały duże sieci handlowe (głównie z kapitałem zagranicznym), które często narzucają warunki sprzedaży dostawcom żywności (firmom spożywczym, producentom rolnym).
\end{abstract}

Słowa kluczowe: rynek, przemysł spożywczy, przetwórstwo żywności, rolnictwo, handel, konsument

\begin{abstract}
The food industry is one of the main elements of the food economy. It is the biggest consumer of raw agricultural materials, and at the same time a primary input into the wholesale trade and retail market. The significance of the food industry is also growing, due to the fact that processing plants often integrate the entities that participate in food manufacturing processes, from the proverbial "field to table." The high quality of Polish agriculture and the increasing demand for highly-processes foods is adding to the growth of the industry. In recent years, large retail chains have gained an advantage in trade relations (mainly with foreign capital). They often impose conditions for the sale of food suppliers (food companies and agricultural producers)
\end{abstract}

Key words: market, food industry, food processing, agriculture, trade, consumer

JEL Classification: E21, E23, L11, Q13

\section{Cel pracy, materiał i metody badawcze}

Celem niniejszego opracowania było pokazanie roli i znaczenia przemysłu spożywczego - jednego z głównych ogniw łańcucha żywnościowego na tle dwóch innych ważnych jego członów, tj. producentów rolnych (dostawców surowców do przetwórstwa) i sfery handlu w ostatnich trzech dekadach. Szczegółową analizą objęto latach 2000-2016, porównując zmiany $\mathrm{w}$ przemyśle spożywczym oraz rolnictwie pod względem liczby podmiotów oraz ich wielkości, wartości produkcji (sprzedanej, globalnej, towarowej), zatrudnienia oraz udziału $\mathrm{w}$ tworzeniu produktu krajowego brutto. Handel detaliczny przedstawiono $\mathrm{w}$ formie opisowej z uwagi na brak porównywalnych danych, chociażby

\footnotetext{
${ }^{1}$ dr inż., IERiGŻ-PIB, ul. Świętokrzyska 20, 00-002 Warszawa, e-mail: Robert.Mroczek@ierigz.waw.pl;
} https://orcid.org/0000-0003-2238-3885 


\section{R. Mroczek}

z tego względu, że wielkopowierzchniowe sklepy (w tym duże sieci handlowe) oferuja duży asortyment produktów (nie tylko żywnościowych), przy czym żywność stanowi przeważająca część oferty handlowej (ponad 50\%), natomiast udział sklepów specjalizujące się w sprzedaży artykułów spożywczych jest relatywnie nieduży i się zmniejsza.

Praca ma charakter analizy porównawczej, w której wykorzystano wtórne materiały źródłowe. Do określenia zmian w czasie posłużono się odpowiednimi wskaźnikami. W opracowaniu wykorzystano przede wszystkim publikowane oraz niepublikowane dane Głównego Urzędu Statystycznego oraz publikacje nawiązujące tematyką do szeroko rozumianej gospodarki żywnościowej.

\section{Ewolucja łańcucha żywnościowego}

Wraz z ewolucją łańcucha żywnościowego, która jest powiązana z rozwojem społeczno-gospodarczym, zmienia się ogniwo wiodące (dominujące) (rys. 1). Jest to proces uwarunkowany wieloma czynnikami. Zmiany $\mathrm{w}$ łańcuchu żywnościowym $\mathrm{w}$ Polsce w ostatnich trzech dekadach P. Chechelski przedstawił w następujący sposób:

1. W Polsce w systemie centralnie planowanej gospodarki głównym ogniwem łańcucha żywnościowego było rolnictwo. Wielkość jego produkcji decydowała o poziomie zaspokojenia potrzeb żywnościowych konsumentów. W tym czasie konsument zaopatrywał się w dużym stopniu bezpośrednio od producentów rolnych. Na początku lat 90 ubiegłego wieku wraz ze zmianami ustrojowymi nastapił wzrost importu artykułów żywnościowych, głównie wysoko przetworzonych, z krajów Europy Zachodniej oraz zmniejszył się eksport surowców rolnych i żywności przetworzonej do krajów dawnego bloku wschodniego. Spowodowało to zmniejszenie się popytu na surowce $\mathrm{z}$ rolnictwa, co w efekcie wpłynęło również na zmniejszenie jego znaczenia w łańcuchu żywnościowym.

2. Prywatyzacja przedsiębiorstw przemysłu spożywczego spowodowała napływ kapitału zagranicznego (gównie z korporacji transnarodowych - KTN), wzrósł popyt krajowy, rozpoczęła się restrukturyzacja przedsiębiorstw krajowych. Wszystko to razem spowodowało dynamiczny rozwój przemysłu spożywczego i w efekcie w latach dziewięćdziesiątych stał się on najważniejszym ogniwem łańcucha żywnościowego.

3. Szybki rozwój globalnych sieci handlowych w pierwszej dekadzie XXI wieku w Polsce zmienił układ sił w łańcuchu żywnościowym. Obecnie ponad $50 \%$ udziału korporacji w handlu artykułami żywnościowymi powoduje, że słabnie dominująca pozycja firm przetwórczych. Swoimi działaniami korporacje handlowe są w stanie wpływać zarówno na: przedsiębiorstwa przemysłu spożywczego (zmuszając je do obniżki kosztów, koncentracji i specjalizacji produkcji, zlecając produkcję pod własnymi markami itd.), rolnictwo (produkcje tanich surowców), przedsiębiorstwa handlowe (do koncentracji i specjalizacji sprzedaży oraz eliminując je z rynku), jak i konsumentów (zmieniając poprzez reklamę i działania marketingowe ich przyzwyczajenia i preferencje żywieniowe).

4. W perspektywie należy spodziewać się, że wraz ze wzrostem edukacji i zamożności społeczeństwa oraz lepsza jego organizacją (poprzez ruchy konsumenckie $\mathrm{i}$ antyglobalne) konsument stanie się najważniejszym ogniwem $\mathrm{w}$ łańcuchu żywnościowym. 


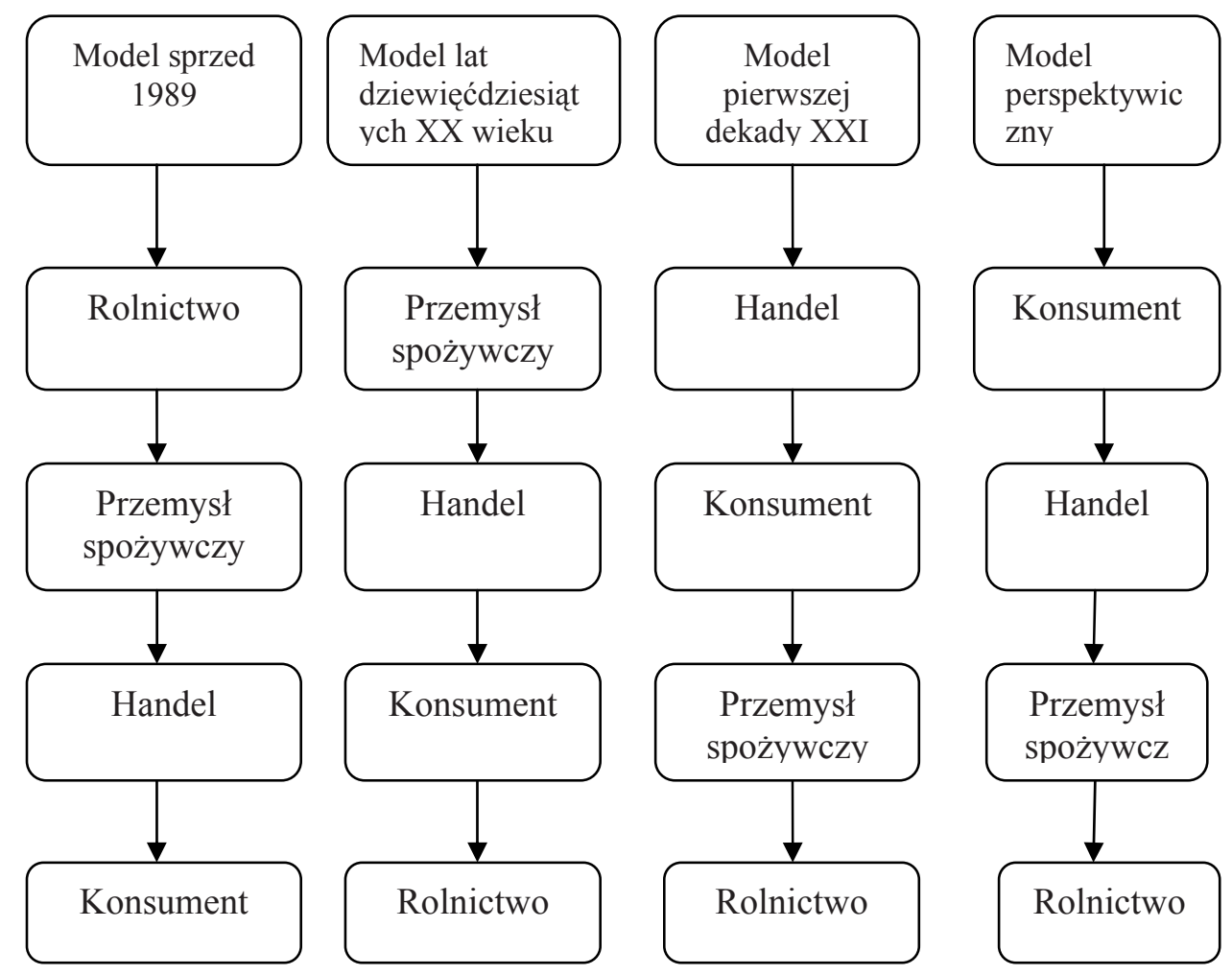

Rys. 1. Ewolucja modelu łańcucha żywnościowego w Polsce zachodząca pod wpływem procesów globalizacji na przełomie XX i XXI wieku

Fig. 1. The evolution of the food chain model in Poland under the influence of globalization processes at the turn of the 20th and 21st centuries

Źródło: Chechelski (2015).

Na szybki rozwój sieci handlowych mają wpływ również procesy globalizacji. Ocena poziomu globalizacji w poszczególnych ogniwach łańcucha żywnościowego w Polsce według badań P. Chechelskiego wskazuje, że w 2012 r. była ona najwyższa w handlu (51\%), wśród konsumentów (48\%), w przemyśle spożywczym wyniosła 43\% a najniższa była w rolnictwie 14-19\% (Chechelski, 2015).

\section{Tendencje rozwojowe rolnictwa, przemysłu spożywczego i handlu po transformacji polskiej gospodarki}

Zmiany ustroju politycznego jakie nastąpiły w Polsce blisko trzy dekady temu, doprowadziły do transformacji gospodarczej kraju, której jednym z filarów miała być gospodarka rynkowa oparta na prawach popytu i podaży. Nowe realia jeżeli nie dla 
wszystkich, to dla większości uczestników rynku były dużą niewidomą i wyzwaniem, a dla niektórych szokiem.

W pierwszych latach transformacji polscy rolnicy, przetwórczy oraz handlowcy podlegali dużym przekształceniom, zwłaszcza własnościowym, choć w różnej skali i tempie. Zlikwidowano m.in. centralne ustalanie cen większości dóbr i usług oraz ograniczono, bądź zaprzestano stosowania dotacji do produkcji.

Rolnictwo jest podstawowym i największym dostawcą surowców rolnych (produktów) do przemysłu spożywczego. Przekształcenia własnościowe w rolnictwie w pierwszych latach transformacji gospodarczej w Polsce dotyczyły przede wszystkim likwidacji państwowych gospodarstw rolnych. Sektor państwowy w rolnictwie polskim w latach 1986-1990, tj. w szczytowym okresie rozwoju, dysponował $19 \%$ ziemi rolnej, wytwarzał $18 \%$ produkcji końcowej i $21 \%$ produkcji globalnej oraz $31 \%$ produkcji towarowej. Utworzona z dniem 1 stycznia 1992 r. Agencja Własności Rolnej Skarbu Państwa (AWRSP) została zobowiązana do przejęcia w ciagu 2 lat (do 1 stycznia 1994 r.) $)^{2}$ mienia po zlikwidowanych PGR-ach, które użytkowały 3,8 mln ha, zatrudniając 204 tys. osób (Zegar, 2018).

Zmiany w rolnictwie indywidualnym, w strukturze gospodarstw przebiegały w różnych kierunkach i wynikały z wielu czynników (w tym m.in. wielkości gospodarstwa). Generalnie po 1990 roku zaczęła zmniejszać się ogólna liczba indywidulanych gospodarstw rolnych (tak powyżej, jak i poniżej 1 ha). Z analiz przeprowadzonych przez J. Fałkowskiego wynika, że w okresie transformacji w grupie gospodarstw najmniejszych (1-2 ha) oraz małych (od 2 do 20 ha) notowano stały spadek ich liczby, natomiast odwrotna sytuacja miał miejsce w przypadku gospodarstw dużych i największych (powyżej 20 i 50 ha), których liczba, wprawdzie powoli, ale systematycznie rosła (Fałkowski, 2010).

Przez ostatnie trzy dekady rolnictwo polskie przeszło duże zmiany. Zmniejszyła się powierzchnia użytków rolnych o 22,9\% z 18,8 mln ha w 1989 r. do 14,5 mln ha w 2016 roku, zmalała liczba gospodarstw rolnych o $41,1 \%$ z 2393,1 tys. do 1410,7 tys., a przeciętna powierzchnia gospodarstwa rolnego wzrosła o 30,4\% z 7,9 ha do 10,3 ha UR.

Wejście Polski do UE oznaczało objecie polskiego rolnictwa Wspólną Polityką Rolną. Wysokość dopłat bezpośrednich wypłacana polskim rolnikom była i jest nadal niższa niż przeciętnie w najbogatszych krajach Unii, tj. UE-15, to jednak ich poziom oraz wsparcie finansowe gospodarstw rolnych, poprzez różne programy pomocowe było większe niż mogłoby na ten cel przeznaczyć państwo polskie ${ }^{3}$. Otrzymane środki finansowe pozwoliły unowocześnić gospodarstwa rolne (zwłaszcza silniejsze ekonomicznie) poprzez zakup nowych maszyn i urządzeń oraz zmodernizować bądź wybudować nowe obiekty produkcyjne. $Z$ drugiej strony dopłaty bezpośrednie w opinii wielu osób, zahamowały szybsze przemiany strukturalne $\mathrm{w}$ polskim rolnictwie. $\mathrm{Z}$ analiz W. Józwiaka wynika, że w 2013 roku było w Polsce 290,7 tys. gospodarstw o wielkości produkcji liczonej w sposób standardowy (SO) przekraczającej 15 tys. euro/gospodarstwo tj. o 14\% więcej niż w 2010 roku (Józwiak, 2017).

W 2015 roku Polska stała się największym w Unii Europejskiej (według wolumenu) producentem mięsa drobiowego, a ponadto jest:

- $\quad$ trzecim producentem zbóż,

\footnotetext{
${ }^{2}$ Proces likwidacji państwowych przedsiębiorstw gospodarki rolnej² zakończył się w 1995 roku. W efekcie zlikwidowanych zostało ponad 1600 PPGR-ów

${ }^{3}$ jeszcze przed wejściem Polski do Unii Europejskiej zaczęły obowiązywać współfinansowane przez UE programy pomocowe, jak, np. PHARE i SAPARD, które dotyczyły środków na rozwój gospodarki żywnościowej
} 
- czwartym producentem mięsa wieprzowego,

- czwartym producentem serów,

- piątym producentem mleka krowiego,

- $\quad$ piątym producentem masła,

- na siódmym miejscu w produkcji mięsa wołowego.

Polska jest także dużym producentem owoców i warzyw w Unii Europejskiej. $\mathrm{W}$ produkcji jabłek i porzeczek jesteśmy liderem. Mamy drugie miejsce $\mathrm{w}$ produkcji truskawek i wiśni. Polska jest największym w Europie producentem buraków czerwonych oraz marchwi, a drugim ogórków. Ponadto jesteśmy największym producentem pieczarek w UE i największym ich eksporterem na świecie. Duzi producenci rolni czy też grupy producenckie mają silniejszą pozycję negocjacyjną wobec firm przetwórczych czy sieci handlowych (Drożdż, Mroczek, 2017).

Wśród strukturalnych czynników określających warunki startu sektora przetwórstwa żywności (przełom lat osiemdziesiątych i dziewięćdziesiątych ubiegłego wieku) w procesy transformacji systemowej R. Urban, wskazuje na niezwykle istotne znaczenie struktury podmiotowej przemysłu spożywczego, które charakteryzowały się następującymi cechami:

- dominacją przedsiębiorstw państwowych, których udział w produkcji tego przemysłu wynosił ok. 75\%, znaczącą rolą centralnie zarządzanej spółdzielczości (ok. 20\%) oraz marginesową i wyłącznie uzupełniającą pozycją sektora prywatnego (ok. 5\%),

- wyraźną przewagą potencjału państwowego, z reguły wielozakładowych przedsiębiorstw, nad małymi i średnimi firmami prywatnymi i spółdzielczymi,

- istnieniem silnych struktur branżowych, które z jednej strony - dokonując podziału zasobów i dotacji - ograniczały samodzielność przedsiębiorstwa i spółdzielni, a z drugiej strony stanowiły branżowe grupy nacisku na władze gospodarcze państwa.

Te cechy powodowały, że wejście do przetwórstwa spożywczego nowych prywatnych podmiotów było niezwykle utrudnione, a istniejące firmy kierowały się zasadą solidarności branżowej, a nie konkurencji czy też rywalizacji. Dlatego też zmiana postaw przedsiębiorstw na właściwe dla gospodarki rynkowej nie mogła być w tym sektorze łatwa i szybka (Urban, 1998).

Dla przyspieszenia procesów dostosowawczych przetwórstwa spożywczego do warunków rynkowych istotne były liberalne regulacje, poprzedzające program L. Balcerowicza, dotyczące prowadzenia działalności gospodarczej i spółek z udziałem kapitału zagranicznego, a także decyzja o urynkowieniu gospodarki żywnościowej z dnia 1.08.1989 r. Regulacje te wcześniej uruchomiły inwestycje w przetwórstwie spożywczym i dały początek nowym firmom, które podjęły rywalizację $\mathrm{z}$ przedsiębiorstwami państwowymi i spółdzielczymi (Urban, 1998).

W latach 1989-1992 uruchomione zostały gwałtowne procesy dostosowawcze przetwórstwa spożywczego do warunków gospodarki rynkowej. Dla tego okresu jak wskazuje R. Urban charakterystyczne były trzy zjawiska: szybki rozwój przetwórstwa lokalnego, silna redukcja produkcji $\mathrm{w}$ firmach przemysłowych oraz globalny spadek przetwórstwa w dziedzinach, w których - po urealnieniu cen - nastąpiła redukcja popytu krajowego lub wzrost samozaopatrzenia.

Rozwój przetwórstwa lokalnego następował trzema sposobami: 
- przez zwiększenie produkcji w rzemiośle spożywczym, które dopiero po zniesieniu ograniczeń w dostępie do surowców, kredytów i rynków zbytu mogło wykorzystać swój potencjał,

- w wyniku szybkiej prywatyzacji przetwórni spółdzielczych i rolniczych,

- $\quad \mathrm{w}$ drodze prywatnych inwestycji w budowę przetwórni, głównie małych i średnich.

W ciagu 2-3 lat powstała gęsta sieć małych zakładów przetwórstwa rolnospożywczego, których liczba zwiększyła się dwukrotnie (do ponad 30 tys. przetwórni). Rozwijały się one głównie w dziedzinie ubojów i przetwórstwa mięsa (łącznie z drobiem), w piekarnictwie i przemiałach zbóż oraz w produkcji napojów, przetworów rybnych i owocowo-warzywnych (Urban, 1998). Do powstawaniu nowych firm (poza wspomnianymi już nowymi regulacjami) przyczynił się również duży popyt wewnętrzny na produkty żywnościowe. Ujawniło się wiele nisz rynkowych, a „wygłodzony” rynek stwarzał warunki łatwego zbytu różnych wyrobów, w tym wyrobów wytwarzanych z zastosowaniem prostych technologii. Uruchomienie ich nie wymagało dużych nakładów kapitałowych, a o sukcesie decydowała umiejętność poszukiwania nisz rynkowych. Łatwiejszy stał się dostęp do surowca, dotacji i subwencji oraz tańszych kredytów. Ważne było także to, że w pierwszej fazie urynkowienia gospodarki żywnościowej wysoka była rentowność przetwórstwa osiagana często kosztem producentów rolnych i konsumentów.

Przetwórstwo lokalne przyjęło wówczas ok. $20 \%$ produkcji firm przemysłowych i zwiększyło swój udział w przetwórstwie żywności do ok. 25-30\%. Osiągnęło ono znaczącą pozycję zarówno w przetwórstwie wstępnym (uboje, przemiał), jak i w produkcji wyrobów przetworzonych (mięsnych, rybnych, pieczywa, napojów) (Urban, 1998).

O ile w pierwszej fazie transformacji nie było istotnych przekształceń w przemysłowej części przetwórstwa, to lata następne były okresem głębokiej przebudowy struktur i sposobu funkcjonowania przemysłu spożywczego. Cechą lat 1993-1998 było:

- powrót tendencji do uprzemysławiania przetwórstwa rolno-spożywczego,

- pogłębienie przetwórstwa żywności,

- przyspieszona modernizacja potencjału wytwórczego sektora,

- szybka i zróżnicowana prywatyzacja przedsiębiorstw państwowych,

- powrót tendencji do koncentracji,

- rozwijanie integracji pionowej i nowoczesnych systemów zarządzania.

W tym okresie wiele nowych firm (zwłaszcza rodzinnych), które powstały na przełomie lata osiemdziesiątych i dziewięćdziesiątych, rozwijało się po przez tzw. „pączkowanie”, czyli dobudowywanie dodatkowych pomieszczeń do istniejących zakładów, zwiększając w ten sposób potencjał produkcyjny.

Wejście Polski do Unii Europejskiej spowodowało koniczność dostosowania się zakładów przetwórczych do nowych norm i wymogów produkcyjnych, sanitarnych i weterynaryjnych. Nie wszystkim przetwórcom udało się spełnić te wymogi. Oznaczało to brak możliwości eksportu swoich produktów na rynek unijny i ukierunkowanie produkcji na rynek lokalny (przy spełnieniu mniej restrykcyjnych wymogów), bądź zaprzestanie produkcji. Branże wrażliwe, tj.: mięsna, drobiarska, mleczarska i rybna objęte zostały okresami przejściowymi. 
Dane zawarte w tab. 1 potwierdzają analizy przeprowadzone przez wielu naukowców ${ }^{4}$, dotyczące zmiany jakie zaszły w polskim rolnictwie w ostatnich dwóch-trzech dekadach.

Tabela1. Podstawowe parametry charakteryzujące rolnictwo oraz przemysł spożywczy w Polsce w latach 20002016

Table 1. Agriculture and food industry in Poland in 2000-2016 - selected characteristics

\begin{tabular}{|c|c|c|c|c|c|}
\hline Wyszczególnienie & 2000 & 2005 & 2010 & 2016 & $\begin{array}{c}\text { Zmiany } \\
\text { w latach } \\
2000-2016 \\
\text { (w proc. rocznie) }\end{array}$ \\
\hline & \multicolumn{5}{|c|}{ Rolnictwo } \\
\hline $\begin{array}{l}\text { Powierzchnia użytków rolnych } \\
\text { (w tys. ha) }\end{array}$ & 17812,0 & 15906,0 & 14859,7 & 14543,3 & $-1,3$ \\
\hline $\begin{array}{l}\text { Liczba gospodarstw rolnych } \\
\text { (w tys.) }\end{array}$ & 2859,2 & 2733,4 & 1509,1 & 1410,7 & $-4,3$ \\
\hline \multicolumn{6}{|l|}{ w tym } \\
\hline $\begin{array}{l}\text { gosp. indywidualnych } \\
\text { (w tys.) }\end{array}$ & 2854,4 & 2728,9 & 1505,0 & 1405,5 & $-4,3$ \\
\hline $\begin{array}{l}\text { Liczba pracujących } \\
\text { (w tys. osób) }\end{array}$ & 4125,3 & 2082,2 & 2326,8 & 2328,7 & $-3,4$ \\
\hline $\begin{array}{l}\text { Produkcja globalna } \\
\text { (w mld zl) }\end{array}$ & 56,0 & 63,3 & 84,5 & 103,4 & 3,9 \\
\hline $\begin{array}{l}\text { Produkcja towarowa } \\
\text { (w mld zł) }\end{array}$ & 33,5 & 42,9 & 59,4 & 76,5 & 5,3 \\
\hline Towarowość produkcji (w \%) & 59,8 & 67,8 & 70,3 & 74,1 & . \\
\hline \multirow[t]{2}{*}{ Udział w PKB (w \%) $)^{\mathrm{a}}$} & 2,3 & 2,3 & 2,2 & 2,1 & . \\
\hline & \multicolumn{5}{|c|}{ Przemysł spożywczy } \\
\hline Liczba firm (w sztukach) & 21977 & 18079 & 15690 & 15613 & $-2,1$ \\
\hline $\begin{array}{l}\text { Liczba pracujących } \\
\text { (w tys. osób) }\end{array}$ & 500,2 & 458,2 & 454,3 & 457,0 & $-0,6$ \\
\hline $\begin{array}{l}\text { Wartość produkcji sprzedanej } \\
\text { (w mln zł) }\end{array}$ & 92,8 & 125,2 & 162,3 & 220,2 & 5,6 \\
\hline Udział w PKB (w \%) ${ }^{\mathrm{a}}$ & 3,0 & 2,8 & 2,7 & 3,0 & . \\
\hline
\end{tabular}

a - mierzony wartością dodaną brutto (WDB)

Źródło: opracowanie własne na podstawie Roczników Statystycznych GUS z lat 2003, 2007, 2017, Rocznika Statystycznego Rolnictwa z 2005 r. oraz niepublikowanych danych GUS.

W latach 2000-2016 w analizowanych sektorach (rolnictwie i przemyśle spożywczym) można wskazać na następujące zjawiska:

- $\quad$ malejący potencjał produkcyjny polskiego rolnictwa w postaci zmniejszenia się powierzchni użytków rolnych o $18,5 \%$ z 17,8 $\mathrm{mln}$ ha do 14,5 $\mathrm{mln}$ ha, przy jednoczesnym wzroście produkcji globalnej rolniczej oraz towarowej odpowiednio o $84,6 \%$ i $228, \%$, tj. o $3,9 \%$ i $5,3 \%$ rocznie (a w cenach stałych o 1,6 i $2,5 \%$ rocznie),

\footnotetext{
${ }^{4}$ m.in. A. Woś, J. Zegar, W. Józwiak
} 
- wzroście towarowości produkcji w rolnictwie o 14,3 pkt. proc. (z $59,8 \%$ do $74,1 \%$ ), co wskazuje na rozwijanie produkcji towarowej, głównie przez większe gospodarstwa rolne powiązane z rynkiem i zaprzestawanie (wygaszanie) produkcji W najmniejszych gospodarstwach, bądź wydzierżawienie ziemi,

- $\quad$ wzrost produkcji globalnej rolniczej oraz towarowej w cenach stałych odpowiednio o 29,5 i 49,0\% wskazuje też na wzrost produktywności ziemi (rekompensujący spadek powierzchni użytków rolnych w badanym okresie) oraz wzrost efektywności (wydajności) produkcji zwierzęcej, co ma o tyle istotne znaczenie, że firmy przemysłu spożywczego zainteresowane są zakupem powtarzalnych, dużych partii surowca do przetwórstwa, a takie mogą zapewnić duże i efektywne gospodarstw rolne, bądź dobrze zorganizowane grupy producenckie,

- duży spadek pracujących w rolnictwie o 43,6\% o 2,3 mln osób (co i tak jest nadal dużą liczbą) i o $8,6 \%$ w przemyśle spożywczym,

- $\quad$ redukcji liczby firm przemysłu spożywczego (o 2,1\% rocznie) i szybkim rozwoju produkcji sprzedanej w tym sektorze (o 5,6\% rocznie), a w cenach stałych o $3,7 \%$ rocznie,

- $\quad$ zmniejszył się udział rolnictwa w tworzeniu PKB Polski z 2,3\% do 2,1\%, natomiast przemysłu spożywczego pozostaje na względnie stabilnym poziomie ok. $3 \%$, co wskazuje na słabnącą pozycję rolnictwa w polskiej gospodarce, ale też względem przemysłu spożywczego.

Inną ważną cechą, na którą trzeba wskazać jest uprzemysławianie produkcji w przetwórstwie spożywczym, czego wyrazem jest rosnący udział przedsiębiorstw dużych (zatrudniających 250 i więcej osób załogi) w produkcji sprzedanej sektora. W latach 20002016 udział ten zwiększył się do 59,7\%, tj. o 8,0 pkt proc., zaś udział średnich i najmniejszych firm zmalał odpowiednio o 4,1 i 3,9 pkt proc.- do 27,0 i 13,3\% (tab. 2).

Tabela 2. Koncentracja produkcji artykułów spożywczych i napojów (bez tytoniu) w Polsce

Table 2. Concentration of food and beverage production (without tobacco) in Poland

\begin{tabular}{|c|c|c|c|c|c|c|c|c|}
\hline \multirow[b]{2}{*}{ Wyszczególnienie } & \multicolumn{2}{|c|}{2000} & \multicolumn{2}{|c|}{2005} & \multicolumn{2}{|c|}{2010} & \multicolumn{2}{|c|}{2016} \\
\hline & $\begin{array}{l}\text { WPS }^{\mathrm{a}} \mathrm{w} \\
\text { mld zł }\end{array}$ & $\begin{array}{l}\text { Udział } \\
\text { w } \%\end{array}$ & $\begin{array}{l}\text { WPS }^{\mathrm{a}} \mathrm{w} \\
\text { mld zł }\end{array}$ & $\begin{array}{c}\text { Udział } \\
\text { w \% }\end{array}$ & $\begin{array}{l}\text { WPS }^{\mathrm{a}} \mathrm{w} \\
\text { mld zł }\end{array}$ & $\begin{array}{c}\text { Udział } \\
\text { w \% }\end{array}$ & $\begin{array}{c}\text { WPS }^{\mathrm{a}} \mathrm{w} \\
\text { mld zł }\end{array}$ & $\begin{array}{c}\text { Udział } \\
\text { w \% }\end{array}$ \\
\hline Firmy ogółem, tym: & 85,1 & 100,0 & 113,6 & 100,0 & 153,7 & 100,0 & 210,7 & 100,0 \\
\hline $\begin{array}{l}\text { - firmy mikro } \\
\text { i małe }\end{array}$ & 14,6 & 17,2 & 19,1 & 16,8 & 23,3 & 15,1 & 28,1 & 13,3 \\
\hline - firmy średnie & 26,5 & 31,1 & 34,3 & 30,2 & 41,3 & 26,9 & 56,9 & 27,0 \\
\hline - firmy duże & 44,0 & 51,7 & 60,2 & 53,0 & 89,1 & 58,0 & 125,7 & 59,7 \\
\hline
\end{tabular}

Źródło: opracowanie własne na podstawie niepublikowanych danych GUS.

W 1990 roku prywatna własność w handlu stanowiła około 94\%. W okresie transformacji gospodarczej w Polsce J. Wrzesińska wyróżnia trzy etapy ekspansji sklepów wielkopowierzchniowych:

- pierwszy to lata 1990-1994 z małą aktywnością rozwojową tego rodzaju sklepów,

- drugi obejmuje lata1995-2003, gdy nastąpił szybki ich rozwój zarówno pod względem liczebności, jak i wysokości obrotów, 
- trzeci okres, od 2004 roku do chwili obecnej, ma niższą dynamikę przyrostu wielkich obiektów handlowych, uwidacznia się tendencja do tworzenia filii dużych sieci handlowych o mniejszej powierzchni sprzedaży i bardziej wyspecjalizowanym profilu podaży (Wrzesińska, 2008).

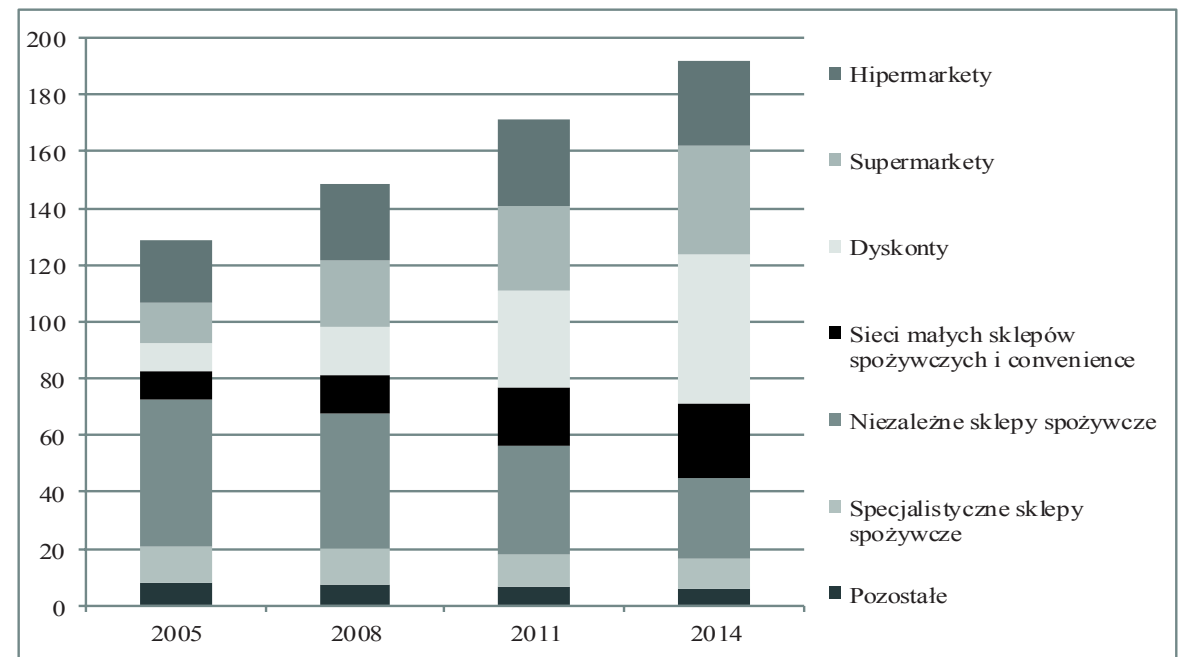

a - dane obejmują całość sprzedaży danego kanału (nie tylko artykuły spożywcze), pominięto stacje benzynowe oraz cash\&carry

Rys. 2. Wartość sprzedaży detalicznej sklepów spożywczych w Polsce (netto, w mld zł)

Fig. 2. Value of grocery retail sales in Poland (net, in PLN billion)

Źródło: opracowanie własne na podstawie opracowania KPMG Na rozdrożu. Wyzwania i priorytety sieci spożywczych w Polsce. Warszawa 201.

Liczba wielkopowierzchniowych obiektów handlowych (WOH) $)^{5}$ w Polsce w 1992 roku wynosiła 1973 sklepy, a w 2007 roku było ich już 7601. Ich udział w ogólnej liczbie sklepów był niewielki, ale z tendencją wzrostową, gdyż w tym okresie zwiększył się on z $0,56 \%$ do $2,08 \%$. W tym czasie liczba wszystkich sklepów zwiększyła się o 5,1\% z 353 tys. do 371 tys. sztuk, przy czym w pierwszej połowie tego okresu (lata 1992-1998) ich liczba wzrosła o 28\%, a potem zaczęła spadać. W latach 1999-2007 największą dynamiką wzrostu liczebności placówek charakteryzowały się hiper i supermarkety, których liczba zwiększyła się odpowiednio czterokrotnie (z 93 do 396) i dwuipółkrotnie (z 1407 do 3506) (Wrzesińska, 2008). Tak szybki wzrost tych placówek wynikał przede wszystkim z tego, że stał za nimi kapitał zagraniczny, liberalnego prawa oraz niezaspokojonych i rosnacych potrzeb konsumentów. W latach 2010-2014 liczba skalpów w Polsce miała lekką tendencję wzrostową, gdyż zwiększyła się o 2,5\% z 346,1 tys. do 354,8 tys. Znacznie szybciej rozwijały się wielkopowierzchniowe obiekty handlowe, których liczba zwiększyła się o prawie 23\% (z 9589 do 11788 sztuk), co oznacza ich dalsze umocnienie w sprzedaży detalicznej żywności. Najszybciej powstawały supermarkety, ich liczba zwiększyła się o 46\% i wyniosła 6509 sztuk. W 2014 roku w 113 tys. sklepów sprzedawano tylko

5 tj. hipermarketów, supermarketów, domów handlowych, domów towarowych. 
żywność. Następną grupę sklepów stanowiły placówki sprzedające artykuły nieżywnościowe (było ich ok. 121 tys.) (Kłosiewicz-Górecka, 2015). Poza tymi sklepami były jeszcze podmioty ze sprzedażą mieszaną gdyż żywność można spożyć w placówkach gastronomicznych, a artykuły spożywcze i napoje można było kupić w centrach handlowych, w kioskach z prasą oraz na stacjach benzynowych.

Z badań firmy audytorsko-doradczej KPMG wynika, że w latach 2005-2014 wartość sprzedaży detalicznej sklepów spożywczych w Polsce zwiększyła się ze 129 mld zł do 192 mld zł (netto) (rys. 2). W tym czasie dyskonty zwiększyły sprzedaż ponad pięciokrotnie, przyczyniając się wraz z supermarketami i sieciami małych sklepów do spadku znaczenia tradycyjnego handlu spożywczego ${ }^{6}$, którego udziały w rynku zmniejszyły się z $56,6 \%$ do $23,2 \%$, tj. o 33,4 pkt proc. (rys. 2). Według szacunków Polskiej Organizacji Handlu i Dystrybucji wartość polskich produktów (w tym żywności i napojów) wyeksportowanych za pośrednictwem sieci handlowych wyniosła w 2014 roku ok. 10 mld zł, tj. ok. 11,5\% całego polskiego eksportu żywności (surowców rolnych i produktów spożywczych), a w 2016 roku mogła wzrosnąc do 11-13 mld zł.

\section{Przetwórstwo jako jeden z głównych członów łańcucha żywnościowego}

Norma ISO 22000 definiuje łańcuch żywnościowy jako sekwencję etapów i procesów mających miejsce w produkcji, przetwórstwie, dystrybucji, magazynowaniu i postępowaniu z żywnością oraz jej składnikami, począwszy od produkcji pierwotnej aż do konsumpcji. Współcześnie do podstawowych ogniw łańcucha żywnościowego zalicza się: rolnictwo, przemysł spożywczy (przetwórczy), handel, konsumentów oraz przemysł środków produkcji i usługi. Jak podkreśla P. Chechelski współczesne łańcuchy żywnościowe to konstrukcje nadzwyczaj skomplikowane, czego przykładem są bardzo rozbudowane pośrednie jego człony tj. przemysłu środków produkcji i usług (Chechelski, 2015).

Efektem zmian, jakie miały miejsce w łańcuchu żywnościowym na przestrzeni ostatnich dziesięcioleci jest:

- dłuższa droga „od pola do stołu” (żywność wysoko przetworzona),

- więcej ogniw pośrednich uczestniczących w łańcuchu żywnościowym (wzrasta anonimowość, a tym samym zagrożenie pod względem bezpieczeństwa i jakości żywności),

- w coraz większym stopniu zunifikowana żywność,

- szybko rosnąca wymiana handlowa surowcami i produktami żywnościowymi w skali świata sprawia, że asortyment na rynku żywności jest coraz większy w poszczególnych krajach,

- postęp w procesie technologicznym i przechowalnictwie wydłużający okres przydatności do konsumpcji,

- silna konkurencja na rynku przyczyniająca się do wprowadzani na rynek tańszej, lecz często o niższej jakości żywności (wykorzystywanie surowców o niższej jakości, z użyciem konserwantów, polepszaczy smaków, barwników itp.),

- trudniejsze monitorowanie historii łańcucha żywności [Kowalczyk 2012].

\footnotetext{
${ }^{6}$ tworzą go przede wszystkim niezależne sklepy spożywcze oraz specjalistyczne sklepy spożywcze.
} 
Przemysł spożywczy, rolnictwo oraz handel różnią się między sobą nie tylko charakterem prowadzonej działalności, ale także parametrami ekonomicznymi opisującymi ich potencjał i wyniki ekonomiczne. Syntetyczne zestawienie wybranych parametrów przedstawiono w tab. 3.

Tabela 3. Podstawowe parametry ekonomiczne polskiego rolnictwa, przemysłu spożywczego oraz handlu detalicznego artykułami żywnościowymi w 2016 roku

Table 3. Basic economic parameters of the Polish farming, the food industry and the retail trade of foodstuffs in 2016

\begin{tabular}{|c|c|c|c|}
\hline Wyszczególnienie & Rolnictwo & $\begin{array}{l}\text { Przemysł } \\
\text { spożywczy }\end{array}$ & $\begin{array}{c}\text { Handel } \\
\text { detaliczny }\end{array}$ \\
\hline Liczba podmiotów (w tys.) & 1411 & 15,6 & $354,0(112,0)^{\mathrm{c}, \mathrm{e}, \mathrm{f}}$ \\
\hline $\begin{array}{l}\text { w tym: towarowych, przemysłowych oraz } \\
\text { wielkopowierzchniowych }^{\text {b }}\end{array}$ & $300-320^{\mathrm{d}}$ & 5,8 & $12,2(7,4)^{\mathrm{c}, \mathrm{e}, \mathrm{f}}$ \\
\hline Liczba pracujących (w tys. osób) & 2328,7 & 457,0 & $450-480^{f}$ \\
\hline $\begin{array}{l}\text { w tym w firmach towarowych, przemysłowych lub } \\
\text { obiektach wielkopowierzchniowych }\end{array}$ & 450 & 400 & $55^{\mathrm{f}}$ \\
\hline \multicolumn{4}{|l|}{$\begin{array}{l}\text { Wartość produkcji (sprzedaży) w cenach bieżących } \\
\text { (w mld zł) }\end{array}$} \\
\hline globalna & 103,4 & 235,1 & . \\
\hline towarowa & 76,5 & 220,2 & . \\
\hline detaliczna & . & . & $229,8^{\mathrm{g}}$ \\
\hline Wartość dodana brutto (w mld zł) & 38,5 & 56,5 & $54,0^{\mathrm{f}}$ \\
\hline Eksport (w mld zł) & 17,0 & 88,9 & $11,0-13^{\mathrm{f}}$ \\
\hline Import (w mld zł) & 25,7 & 49,7 & $10,0-13,0^{\mathrm{f}}$ \\
\hline $\begin{array}{l}\text { Wartość spożycia żywności, napojów i wyrobów } \\
\text { tytoniowych oraz narkotyków }{ }^{\mathrm{h}} \text { (w mld zł) }\end{array}$ & & $246,0\left(270,0^{f}\right)^{i}$ & \\
\hline
\end{tabular}

a - prowadzony głównie przez małe sklepy detaliczne o różnej formie prawnej oraz obiekty wielkopowierzchniowe (super i hipermarkety, domy towarowe, domy handlowe),

b - obiekty wielkopowierzchniowe - to sklepy, których powierzchnia sprzedażowa ma 401 i więcej $\mathrm{m}^{2}$,

c - z tej grupy sklepów - ok.112,0 tys. sprzedawało art. żywnościowe ogółem, jak też były to sklepy specjalistyczne, np. mięsne, rybne, piekarniczo -ciastkarskie, sklepów z artykułami nieżywnościowymi było ok. 121,0 tys.,

d - szacunek gospodarstwa o wielkości produkcji liczonej w sposób standardowy (SO) przekraczającej 15 tys. euro/gospodarstwo,

e - sklepy wielkopowierzchniowe, $\mathrm{z}$ których 7,4 tys. to super i hipermarkety,

$\mathrm{f}$ - szacunek,

g - wartość sprzedaży detalicznej art. żywnościowych wraz z napojami oraz alkoholem i wyrobami tytoniowymi realizowana przez sklepy detaliczne łącznie ze sprzedażą detaliczną dokonywaną w hurtowniach i u producentów, $\mathrm{h}$ - stanowi sumę spożycia prywatnego, tj. spożycia w sektorze gospodarstw domowych i sektorze instytucji niekomercyjnych działających

na rzecz gospodarstw domowych oraz spożycia indywidualnego w sektorze instytucji rządowych i samorządowych,

$\mathrm{i}$ - z żywieniem zbiorowym (rynek HoReCa)

Źródło: Rocznik Statystyczny GUS 2017 r. oraz obliczenia własne na podstawie Eurostatu i niepublikowanych danych GUS o liczbie przedsiębiorstw przemysłu spożywczego.

Zróżnicowane parametry ekonomiczne są wynikiem następujących zjawisk:

- wartość produkcji globalnej przemysłu spożywczego jest ponad dwukrotnie większa niż rolnictwa, a wartość produkcji sprzedanej tego przemysłu jest blisko 3 razy większa od produkcji towarowej rolnictwa i na podobnym poziomie, jak sprzedaż detaliczna, 


\section{R. Mroczek}

- wartość dodana brutto przemysłu spożywczego jest o ok. $47 \%$ większa niż wytworzona przez producentów rolnych porównywalna z tą ze sprzedaży detalicznej żywności,

- liczba pracujących w przemyśle spożywczym jest pięciokrotnie mniejsza niż w rolnictwie oraz porównywalna do liczby osób pracujących w handlu detalicznym.

Cechą wspólną analizowanych członów łańcucha żywnościowego w Polsce w ostatnich dwóch dekadach, było umacnianie pozycji dużych (w tym największych) graczy rynkowych. Nastapił wzrost koncentracji produkcji w sferze produkcji i przetwórstwa żywności oraz zwiększyła się dominacja dużych sieci handlowych, często o zasięgu globalnym.

Umocnienie pozycji dużych sieci handlowych w łańcuchu dostaw w ostatnich latach, to też wynik wsparcia kapitału zagranicznego, gdyż ich siedziby ulokowane są za granicą. Ponadto sieci handlowe w umiejętny sposób korzystały, zwłaszcza w pierwszych latach swojej ekspansji na rynku polskim z ulg podatkowych, co też stanowiło obiektywnie patrząc, element nieuczciwej konkurencji wobec innych podmiotów (sklepów).

Rynek żywnościowy podlega ciagłym zmianą. Są one wynikiem dostosowywania oferty handlowej do potrzeb klientów, dużej konkurencji, a także zmian w prawie. W ostatnich latach szybko rozwija się w Polsce rynek HoReCa (szeroko rozumiany segment gastronomiczny) i według firmy badawczej PMR sprzedaż żywności w tym kanale dystrybucji w 2017 roku mogła osiagnąć wartość ok. 24 mld zł. Rozwój tego segmentu rynku wynika m.in. z poprawy sytuacji ekonomicznej społeczeństwa i częstszego stołowania się po za domem.

W ostatnim czasie sporo mówi się też o skróceniu łańcucha dostaw. Zgodnie z rozporządzeniem Parlamentu Europejskiego i Rady (UE) nr 1300/2013 dotyczącym rozwoju obszarów wiejskich krótki łańcuch dostaw oznacza łańcuch dostaw obejmujący ograniczoną liczbę podmiotów gospodarczych zaangażowanych we współpracę oraz lokalny rozwój gospodarczy. Stwarza to potencjalne korzyści dla środowiska, gospodarki oraz społeczeństwa. Jak zauważają S. Jarzębowski i N. Bezat niekoniecznie wszystkie krótkie łańcuchy dostaw będą przynosić oczekiwane korzyści (Jarzębowski, Bezat, 2018). Dzięki wdrożeniu krótkich łańcuchów dostaw możliwe jest uzyskanie przez rolników wyższych marż przy niższych kosztach ogólnych niż w przypadku dłuższych łańcuchów dostaw. Kolejną korzyścią krótkich łańcuchów dostaw jest ograniczenie konkurencji między wieloma małymi i dotychczas niekoordynowanymi łańcuchami dostaw $\mathrm{w}$ regionie. Ważną rzeczą jest efektywność łańcuch dostaw, która wpływa na konkurencyjność i zrównoważony rozwój całego sektora rolno-spożywczego. Jest to ważna kwestia zwłaszcza w odniesieniu do producentów rolnych, gdy pośrednicy przejmują część profitów, które mogliby otrzymać rolnicy i w ten sposób więcej zarobić. Wydaje się, że dla przemysłu spożywczego, jako całego byłoby to bez większego znaczenia, chociażby z tego względu, że tylko w niektórych branżach udział pośredników jest jeszcze znaczący, przede wszystkich w obrocie żywcem wołowym i w mniejszym stopniu żywcem wieprzowym.

Większe korzyści przemysł spożywczy może osiagnąć z poprawy relacji handlowych z dużymi odbiorcami, jakimi są duże sieci handlowe. Polska zabiega, aby kwestie nieuczciwych praktyk handlowych zostały uregulowane na poziomie unijnym. Jednocześnie $\mathrm{w}$ jak największym stopniu powinny one uwzględniać rozwiązania już przyjęte przez państwa członkowskie, w drodze przepisów krajowych. Polska przyjęła w 2017 roku ustawę o zakazie stosowania nieuczciwych praktyk w sektorze rolnospożywczym. W ocenie byłego ministra rolnictwa K. Jurgiela lista nieuczciwych praktyk jest długa i obejmuje m.in.: 
- opóźnione płatności za produkty szybko psujące się,

- anulowanie zleceń w ostatniej chwili,

- jednostronne zmiany warunków umowy lub zmiany tychże warunków z mocą wsteczna,

- żądania, aby dostawcy płacili za zmarnowane produkty żywnościowe.

Rolę i znaczenie przemysłu spożywczego w łańcuchu żywnościowym można rozpatrywać w różnych aspektach, np.:

\section{ekonomicznym}

- podobnie jak inne działy gospodarki, wnosi wkład w tworzenie produktu krajowego brutto,

- dynamicznie rozwijający się eksport produktów spożywczych po wejściu Polski do Unii Europejskiej oraz jego dodatnie saldo wymiany handlowej ograniczał deficytu wymiany handlowej Polski, a obecnie poprawia dodatnie saldo wymiany handlowej.

\section{społeczno-ekonomicznym}

- zapewnia miejsca pracy,

- przyczynia się do kreowania zmian w jakości produkowanych surowców rolnych poprzez wyższe wymagania stawiane ich producentom,

- zakłady przemysłu spożywczego wychodzą naprzeciw gustom i oczekiwaniom konsumentów, co do jakości i asortymentu produkowanej żywności,

- zakłady przetwórcze rozwijając eksport swoich produktów, promują polską żywność za granicą oraz zagospodarowują jej nadwyżki,

- przemysł spożywczy łagodzi gwałtowne wzrosty cen skupu produktów rolnych (Mroczek, 2017),

- zapewnia bezpieczeństwo żywnościowe konsumentom, ponieważ jako wytwórca żywności i podmiot odpowiedzialny jest za wprowadzany na rynek produkt ${ }^{7}$,

Podstawową rolą przemysłu spożywczego jest wytwarzanie żywności i napojów z surowców rolnych, które poddane mniejszemu lub większemu przetworzeniu w kolejnych etapach dystrybucji łańcucha żywnościowego (handlu, gastronomii) oferowane są konsumentowi. $\mathrm{W}$ ten sposób przetwórstwo wraz z rolnictwem oraz handlem zabezpiecza jedną z podstawowych potrzeb bytowych człowieka, jaką jest zaspokojenia głodu.

Zakłady przemysłu spożywczego pełnią często funkcję integratora podmiotów biorących udział w procesie produkcji od pola do stołu. Jednak jak zauważa R. Urban rolę tę coraz częściej mogą przejmować handel i duże sieci handlowe, gdyż to one zaczynają odgrywać rolę dominującą w łańcuchu żywnościowym (Urban, 2012). Zmieniające się uwarunkowania zewnętrzne $\mathrm{i}$ wewnętrzne wymuszają na firmach spożywczych poszukiwanie nowych rozwiązań i dostosowywanie się do potrzeb finalnych odbiorców żywności, jakimi są konsumenci.

Polska jest szóstym producentem wyrobów przemysłu spożywczego w Unii Europejskiej z udziałem wynoszącym 8,5\% (w 2004 roku było to 6,9\%). Wyraźnie wyprzedzaja nas: Niemcy, Francja, Włochy i Hiszpania, a w nieco mniejszym stopniu Wielka Brytania (Mroczek, 2017).

\footnotetext{
${ }^{7}$ Wytyczne te zawarte są w podstawowym rozporządzeniu higienicznym (WE) nr 852/2004.
} 


\section{Podsumowanie}

1. W ostatnich trzech dekadach cały sektor żywnościowy w Polsce podlegał dużym zmianom, tak pod względem ilościowym, jak i jakościowym. W przemyśle spożywczym zmniejszyła się liczby firm, a modernizacja zakładów przetwórczych, wymiana linii produkcyjnych, poprawiła efektywność produkcji i rozszerzyła ofertę handlową. Mniejsza liczba firm $\mathrm{z}$ powodzeniem zwiększała sprzedaż i zagospodarowywała nadwyżki w produkcji rolniczej, czemu sprzyjał szybko rosnący eksport polskiej żywności po przystąpienie do Unii Europejskiej.

2. Szybko przebiegające procesy dostosowawcze krajowego przemysłu spożywczego do zmieniającego się otoczenia rynkowego, spowodowały, że sektor ten ma pozycję dominująca w odniesieniu do producentów rolnych, gdyż jest silniejszym podmiotem, co wynika m.in. z większej koncentracji produkcji, natomiast w stosunku do dużych sieci handlowych (za którymi często stoi kapitał zagraniczny), jego pozycja jest już słabsza, co wynika m.in. z mniejszej siły przetargowej oraz dużej konkurencji między firmami przemysłu spożywczego.

3. Wzmocnienie pozycji przetargowej firm przemysłu spożywczego w Polsce względem dużych sieci handlowych, może ulec pewnej poprawie, poprzez odpowiednie regulacje prawne, które jeżeli nie wyeliminują, to ograniczą tzw. nieuczciwe praktyki handlowe stosowane przez sieci handlowych.

\section{Literatura}

Chechelski, P. (2015). Ewolucja łańcucha żywnościowego (Evolution of food chain). W: I. Szczepaniak, K. Firlej (red.), Przemysł spożywczy - makrootoczenie, inwestycje, ekspansja zagraniczna (Food industry - macro environment, investments, foreign expansion). Uniwersytet Ekonomiczny w Krakowie, IERiGŻ-PIB w Warszawie. Kraków - Warszawa, 45-63.

Fałkowski, J. (2010). Zmiany liczby gospodarstw rolnych w Polsce w okresie transformacji (Changes in the number of farms in Poland during the transition). Gospodarka Narodowa, 1-2, 89-108.

Grauer, P., Kulig, M., Kuskowski, P., Matusik, M. (2015). Na rozdrożu. Wyzwania i priorytety sieci spożywczych w Polsce (At the crossroads. Challenges and priorities of food chains in Poland). KPMG, Warszawa. Pobrano z: https://assets.kpmg.com/content/dam/kpmg/pdf/2016/03/Raport-KPMG-Na-rozdrozuWyzwania-i-priorytety-sieci-spozywczych-w-Polsce.pdf.

Jarzębowski, S., Bezat, N. (2018). Zarządzanie krótkimi łańcuchami dostaw. Branża spożywcza (Management of short supply chain. Food industry). Przemyst Spożywczy 1(72), 44-46.

Józwiak, W. (2017). Ocena możliwości rozwojowych gospodarstw rolnych średniej wielkości (Assessment of developmental possibilities of farms with average economic size). W: W. Józwiak (red.) Przedsiębiorstwo i gospodarstwo rolne wobec zmian klimatu i polityki rolnej (3) (Farms and agricultural enterprises in the face of climatic change and the changes in the agricultural policy), seria „Monografie Programu Wieloletniego 2015-2019" nr 51, IERiGŻ-PIB, Warszawa 48.

Kłosiewicz-Górecka, U. (2015). Handel detaliczny - zasoby, formaty i tendencje (Retail - resources, forms and tendencies). W: Handel wewnętrzny w Polsce 2010-2015. (Domestic trade in Poland in 2010-2015) IBRKiK, Warszawa, 136-149.

Kowalczyk, S. (2012). Konsekwencje globalizacji dla rolnictwa europejskiego (Consequences of globalisation for European agriculture). W: S. Kowalczyk Globalizacja i regionalizacja w stosunkach międzynarodowych (Globalisation and regionalisation in international relations), SGH, Warszawa.

Mroczek, R. (2017). Przemysł spożywczy (Food industry). W: J. Drożdż. R. Mroczek (red.) Przetwórstwo produktów pochodzenia zwierzęcego w Polsce w latach 2010-2016 (Processing of animal products in Poland in 2010-2016), seria „Monografie Programu Wieloletniego 2015-2019” nr 68, IERiGŻ-PIB, Warszawa 120, 138-139.

Rocznik Statystyczny 2003 (Statistical Yearbook 2003). GUS, Warszawa. 
Rocznik Statystyczny 2007 (Statistical Yearbook 2007). GUS, Warszawa.

Rocznik Statystyczny 2017 (Statistical Yearbook 2017). GUS, Warszawa.

Rocznika Statystycznego Rolnictwa 2005 (Statistical Yearbook of Agriculture 2005). GUS, Warszawa.

Rozporządzenie Parlamentu Europejskiego i Rady (UE) nr 1300/2013 z dnia 17 grudnia 2013 r. w sprawie FS i uchylające rozporządzenie (WE) nr 1084/2006 (Regulation (EU) no 1300/2013 of the European Parliament and of the Council of 17 December 2013 on the Cohesion Fund and repealing Council Regulation (EC) No 1084/2006)

Urban, R. (1998). Przemysł spożywczy w procesie transformacji systemowej (Food industry in transition). W: A. Woś (red.) Rolnictwo polskie w okresie transformacji systemowej (Polish agriculture in transition), IERiGŻ Warszawa, 83-101.

Urban, R. (2012). Ocena spójności procesów rozwojowych rolnictwa i przemysłu spożywczego (Assessment of the cohesion processes of agriculture and food industry). Zagadnienia Ekonomiki Rolnej, 1, 3-17.

Wrzesińska, J. (2008). Rozwój wielkopowierzchniowych obiektów handlowych w Polsce (Development of big shopping centres in Poland). ZN SGGW Ekonomika i Organizacja Gospodarki Żywnościowej, 72, 161-170.

Zegar, J.S. (2018). Kwestia agrarna w Polsce (Agrarian issue in Poland). IERiGŻ-PIB, Warszawa.

\section{Do cytowania / For citation:}

Mroczek R. (2018). Pozycja przemysłu spożywczego w łańcuchu żywnościowym w Polsce na przełomie XX/XXI wieku. Problemy Rolnictwa Światowego, 18(4), 23-37;

DOI: $10.22630 /$ PRS.2018.18.4.94

Mroczek R. (2018). The Position of the Food Industry in Poland's Food Chain at the Turn of the $20^{\text {th }}$ to the $21^{\text {st }}$ Century (in Polish). Problems of World Agriculture, 18(4), 23-37;

DOI: 10.22630/PRS.2018.18.4.94 